A Compar at i ve St udy on the Pr esent Gover nment Procurement Act and Act for Promti on of Private Partici pat i on in I nf rastructure Proj ect s in Tai wan

\begin{tabular}{|c|c|}
\hline 著者 & Po- Wen Huang \\
\hline $\begin{array}{l}\text { jour nal or } \\
\text { publ i cat i on } \mathrm{title}\end{array}$ & $\begin{array}{l}\text { I nt er nat i onal Revi ew for Spat i al PI anni ng and } \\
\text { Sust ai nabl e Devel opment }\end{array}$ \\
\hline vol une & 4 \\
\hline number & 3 \\
\hline page $r$ ange & $58-69$ \\
\hline year & 2016-07- 15 \\
\hline URL & ht t p: //hdl . handl e. net /2297/45840 \\
\hline
\end{tabular}




\title{
A Comparative Study on the Present Government Procurement Act and Act for Promotion of Private Participation in Infrastructure Projects in Taiwan
}

\author{
Po-Wen Huang ${ }^{1 *}$ \\ 1 College of Design, National Taipei University of Technology \\ * Corresponding Author, Email: royaa6417@cpami.gov.tw
}

Received: 10 Septempber, 2015; Accepted: 19 February, 2016

Key words: Government Procurement Act (GPA), Act for Promotion of Private Participation in Infrastructure Projects (PPP)

\begin{abstract}
In Taiwan, government staff, judicial officers and private institution owners should avoid erroneously misapplying the Government Procurement Act (GPA) and the Act for Promotion of Private Participation in Infrastructure Projects (PPP). This study examined the literature and conducted a comparative analysis of the legislation processes related to the Act for Promotion of Private Participation in Infrastructure Projects and the Government Procurement Act. The differences between these two Acts, as well as the government's promotion of private participation in infrastructure projects, were explored by investigating the spirit of the laws, open procedures, security measures, private sector participation and measures that promote public interest and prevent fraud. In conclusion, the historical background, legislative purpose, implementation procedures, transparency and confidentiality regulations are found to be fundamentally different between the two Acts. Because of this, executives should avoid erroneously misapplying laws.
\end{abstract}

\section{RESEARCH BACKGROUND AND PURPOSES}

When formulating national infrastructure plans, the government must consider how to prevent fraud and promote public interest. If fraud prevention measures are strict, then civil servants tend to perform their duties rigorously and are likely to take on fewer tasks in order to avoid making mistakes; however, infrastructure developments may be delayed and the use of public space may become inefficient. By contrast, if promoting public interest is the main focus, then risk management is disregarded and the social benefits of infrastructure development are not maximized. Therefore, developing a system for promoting public interest and preventing fraud simultaneously is crucial to the promotion of national infrastructure development.

In Taiwan, despite previous governments allocating large budgets to developing national infrastructure, they were ineffective in supervising procurement, bidding and compliance procedures, resulting in low-quality public works. Some civil servants have been subjected to judicial investigations and prosecutions because of conflicting interests. Therefore, to establish an open and fair procurement procedure and to enhance procurement 
efficiency, the Executive Yuan promulgated the Government Procurement Act in 1998, in which procurement regulations were stipulated (including regulations for bid rigging and bid collusion) to prevent corruption, minimize poor budgetary spending and improve the quality of public works.

Infrastructure developments are typically undertaken to stimulate economic growth. Although the government is responsible for such developments, private funds can be acquired and professional technologies can be introduced by adopting a user-pay system to facilitate infrastructure development and to ease governmental financial pressure. Therefore, to enhance the quality of public services and to stimulate socioeconomic development, the Act for Promotion of Private Participation in Infrastructure Projects was enacted in 2000. Through private institutions' participation in public infrastructure operations, private institutions are independently liable, effectively responsible, for the performance of such operations and share their profits with the government to improve people's quality of life, achieving a beneficial outcome for the government, private institutions and the public.

In Taiwan, national infrastructure development is undertaken in accordance with the 1998 Government Procurement Act and the 2000 Act for Promotion of Private Participation in Infrastructure Projects. Before the Act for Promotion of Private Participation in Infrastructure Projects was enacted, public-private partnerships in infrastructure development were conducted in accordance with Article 99 of the Government Procurement Act, which states that companies (i.e., suppliers) who are qualified to develop infrastructure related to transportation, energy, environmental protection and tourism shall be selected by the competent authority in accordance with this article, unless provided for by other regulations. Accordingly, determining which Act should be applied when commissioning infrastructure developments is debatable. Governmental staff, judicial officers and private institution owners have often mistakenly applied the Government Procurement Act for the Act for Promotion of Private Participation in Infrastructure Projects. Furthermore, the Act for Promotion of Private Participation in Infrastructure Projects has frequently been confused with the Government Procurement Act, and the spirit of these laws has frequently been misused (Division for Promotion of Private Participation, 2006a; Public Construction Commission, 2007).

Article 2 of the Act for Promotion of Private Participation in Infrastructure Projects states that this Act prevails when promoting private sector participation in infrastructure projects. Therefore, the government must evaluate which Act their plans should be implemented in accordance with; the government should clearly define their plans in order to promote public interest and prevent fraud.

\section{RESEARCH METHODS}

This study examines the literature and conducts a comparative analysis of the legislation processes related to the Act for Promotion of Private Participation in Infrastructure Projects and the Government Procurement Act. The differences between these two Acts as well as the government's promotion of private participation in infrastructure projects were explored by investigating the spirit of the laws, open procedures, security measures, private sector participation and measures that promote public interest transparency and prevent fraud. 


\section{EVOLUTION OF THE GOVERNMENT PROCUREMENT ACT}

Before the Government Procurement Act was enacted, procurement for public works was performed in accordance with the Enforcement Rules of the Audit Act, the Ordinance Concerning Inspection Procedure Governing Construction Work, Procurement and Disposal of Properties by Government Agencies (hereafter referred to as "the Inspection Ordinance," which was based on Article 59 of the Audit Act), and/or Guidelines for Invitations to Tender for Public Construction Works Drafted by the Executive Yuan (The Legislative Yuan of the Republic of China, 1994). Therefore, in Taiwan, the government developed public works in accordance with the Audit Act. The Inspection Ordinance, which contained only 24 regulations, was enacted in 1950 and abolished in 1999 after being in effect for 49 years.

The Inspection Ordinance was abolished in response to countries worldwide removing trade and tariff barriers in order to promote free trade, including the drafting of the 1947 Agreement on Government Tax and Trade (GATT); in 1995, the World Trade Organization (WTO) was established. To address the challenges of globalization, in 1990 Taiwan applied for participation in the GATT forum and became the $144^{\text {th }}$ WTO member in 2002. Among the various WTO agreements, the current Agreement on Government Procurement, which was concluded in Uruguay in 1993, is most directly relevant to public works. When Taiwan applied for accession into the WTO, other countries requested that Taiwan first open its government-procurement market in order to conform to the Agreement on Government Procurement. Accordingly, the Government Procurement Act (GPA) was enacted in 1998 in accordance with the agreement and relevant regulations.

Here, the differences between the WTO-GPA and the Taiwan Government Procurement Act are outlined. The rules of transparency, equality and nondiscrimination set by the GATT have already been complied with through the Taiwan Government Procurement Act. Differences between the WTO-GPA and Taiwan Government Procurement Act focus on three areas: Execution procedure, list of promised open-industries, and financing boundary. From 2015 to 2016, the WTO-GPA set the financing limit for procurement to $\$ 228,100,000$ NTD (Public Construction Commission, 2016a).

\section{LEGISLATION PROCESS FOR PPP IN INFRASTRUCTURE PROJECTS}

Enactment of the Act for the Promotion of Private Participation in Infrastructure Projects was preceded by the 1929 Privately Owned Public Utilities Supervisory Act and then the 1953 Statute of Privatization of Government-Owned Enterprises, which was not passed by the Legislative Yuan until 1991. In 1993, consensus was reached on a review report regarding a 6-year national development plan, and Taiwan began promoting private participation in infrastructure projects $(\underline{\mathrm{Li}, 2015})$. Subsequently, the Statute for Encouragement of Private Participation in Transportation Infrastructure Projects was enacted in 1994 (The Legislative Yuan of the Republic of China, 1994).

In 1995, the National Development Council in the Executive Yuan adopted a build-operate-transfer model in managing 22 projects aimed at promoting 
national infrastructure development, including the north-south high-speed railway. In 1996, the National Development Council held a conference on national development, which culminated in the implementation of the Statute for Encouragement of Private Participation in Transportation Infrastructure Projects. The conference was aimed at modifying the range of legal applicability, as well as to form a legal basis for promoting private participation in infrastructure projects. Accordingly, the Act for Promotion of Private Participation in Infrastructure Projects was enacted in 2000 ((Division for Promotion of Private Participation, 2006b; The Legislative Yuan of the Republic of China, 1998). In addition, the Statute for Encouragement of Private Participation in Transportation Infrastructure Projects applied to investment contracts related to private participation until the statute was replaced with the Act for Promotion of Private Participation in Infrastructure Projects, which was deemed advantageous to private institutions. Subsequently, the statute was no longer valid under law.

\section{ISSUES WITH THE GPA AND PPP IN INFRASTRUCTURE PROJECTS}

\subsection{The Constitution of Taiwan does not clearly distinguish the differences between service provision and gaining illegal profits, which leads to the possibility of law-abiding civil servants being subject to prosecution}

In 2005, at the $995^{\text {th }}$ ministry meeting, the Minister of Justice proposed relaxing the Act for the Promotion of Private Participation in Infrastructure Projects, and that concessions should be made to encourage private participation in infrastructure projects. This Act is a special law because it prevails over other related laws and is thus critical for law enforcement officers investigating cases relating to illegal profits. An offense involving illegal profit obtainment is judged on the basis of whether the involved persons have deliberately violated any law. "Deliberately violating a law" is a crucial element in a case for which the law related to inviting investors has been infringed upon. Regarding the procurement of evidence, according to Item 3 of Article 6 of the Government Procurement Act, the competent authority shall assist or provide counsel to the Judicial Yuan or Control Yuan when investigating, accusing, impeaching, or censuring procurement agencies or staff. If questions arise regarding whether cases are related to the Act for Promotion of Private Participation in Infrastructure Projects, the regulations in this Act stipulate when the competent authority shall assist or provide counsel to determine which Act shall prevail in order to prevent incidents of misjudgment.

\subsection{Issues with how the government promotes private participation in infrastructure projects}

\subsubsection{Problems concerning the PPP system}

Institute of Transportation (2009) examined cases in which the Act for the Promotion of Private Participation in Infrastructure Projects (referred to as 
"the Act" in this section) has been enforced and identified the following issues:

(1) Real estate securitization: Public works cannot yield profits, which hinder business operations through public facilities; therefore, real-estate securitization and land trust cannot be implemented.

(2) Ambiguity between private and public investment contracts: The Act is unclear about whether investment contracts are considered private or public contracts.

(3) Entitlement premiums and rebates: To prevent conflicts of interest created by personnel involved in the Act, high entitlement premiums are offered; however, this hinders the number of services offered and improvements in service quality.

(4) Low awareness of how public works benefit the general public and the protection of disadvantaged groups: Discussions about public interest have been insufficient. For example, media coverage on subsidies for disadvantaged groups and environmental protection are not objective, which generate negative publicity about the Act.

(5) Need for an independent regulatory commission: In Taiwan, "a competent authority" is responsible for regulating utility rates, however, in other developed countries utility rates are regulated openly and fairly by an independent commission.

\subsubsection{Factors contributing to conflicts of interests in the Act}

Ministry of Finance (2015) reported $64.3 \%$ of the difficulties that government agencies have encountered related to the promotion of private participation in infrastructure projects were inexperience, poor advice, low professionalism among project executives and disputes with private enterprises who are eyeing up profits. Consequently, government agencies are hesitant about promoting private participation in infrastructure projects or are overly conservative when undertaking such projects.

In 2007, the Public Construction Commission of the Executive Yuan, an independent agency of the Executive Yuan, indicated that government agencies have encountered the following problems with the promotion of private participation in infrastructure projects: Unfamiliarity with the Act for Promotion of Private Participation in Infrastructure Projects; Government agencies mistakenly adopting the Government Procurement Act in cases where the Act for Promotion of Private Participation in Infrastructure Projects should be applied (and vice versa).

\subsection{Most Government staff are unfamiliar with PPP Act}

Government staff (accountants, auditors, accounting and statistics officers, ethics officials and prosecution and investigation officers) are unfamiliar with the Act for Promotion of Private Participation in Infrastructure Projects. Ministry of Finance (2014) hosted a forum to discuss issues about promoting private participation in infrastructure projects. The representative for the northern region of Taiwan argued that many civil servants lack experience and professional knowledge in promoting private participation in infrastructure projects, consequently, in the event of problems, the project manager is held accountable. In addition, civil servants are not encouraged to promote private participation in infrastructure projects and the Ministry of Finance lacks comprehensive guidelines, providing inadequate assistance to help project managers in solving problems. Furthermore, information presented at a seminar on political morality and government procurement erroneously 
referred to cases related to the Act for Promotion of Private Participation in Infrastructure Projects as being related to the Government Procurement Act. ${ }^{1}$ Similar problems have been encountered by both infrastructure project managers as well as staff in accounting, auditing, statistics, political morality, and prosecution divisions.

\section{INTERNATIONAL TREND OF CIVIL PARTICIPATION IN PUBLIC WORKS}

In order to utilize civil strength in public works, the British government began their promotion of private participation in infrastructure with the Channel Tunnel project between the UK and France in 1987. Based on different domestic environments, countries around the world have developed many mechanisms for private participation in infrastructure, such as: BuildOperate-Transfer (BOT), Build-Own-Operate (BOO), Build-TransferOperate (BTO), Private-Finance-Initiative (PFI), Build-Transfer-Lease (BTL), and Design-Build-Finance-Operate (DBFO). The summary is below (Elbing \& Wettengel, 2011; Public Construction Commission, 2016b; Deautschland, $\underline{2008)}$ :

Table 1. Shows trend of PPP in the following countries

\begin{tabular}{|c|c|c|c|c|c|c|}
\hline Nation & Law & Scope & $\begin{array}{l}\text { Administrat } \\
\text { ion }\end{array}$ & $\begin{array}{c}\text { Government } \\
\text { Organizatio } \\
n\end{array}$ & $\begin{array}{c}\text { Non-public } \\
\text { Organizatio } \\
n\end{array}$ & $\begin{array}{c}\text { Private } \\
\text { company } \\
\text { applying } \\
\text { project } \\
\text { by itself } \\
(\mathrm{Y} / \mathrm{N})\end{array}$ \\
\hline Taiwan & $\begin{array}{l}\text { Specific } \\
\text { law, and } \\
\text { gradually } \\
\text { establishi } \\
\text { ng } \\
\text { working } \\
\text { procedure } \\
\text { and } \\
\text { standard } \\
\text { contract }\end{array}$ & $\begin{array}{l}\text { Transportati } \\
\text { on facilities } \\
\text { and common } \\
\text { conduits; } \\
\text { environment } \\
\text { al pollution } \\
\text { prevention } \\
\text { facilities; } \\
\text { sewerage, } \\
\text { water supply } \\
\text { and water } \\
\text { conservancy } \\
\text { facilities etc. }\end{array}$ & $\begin{array}{l}\text { Administrat } \\
\text { ive } \\
\text { department } \\
\text { is } \\
\text { department } \\
\text { of } \\
\text { construction } \\
\text {; central, } \\
\text { county and } \\
\text { city } \\
\text { government }\end{array}$ & $\begin{array}{l}\text { Executive } \\
\text { Yuan Public } \\
\text { Infrastructur } \\
\text { e } \\
\text { Committee, } \\
\text { Executive } \\
\text { Yuan } \\
\text { promoting } \\
\text { civil } \\
\text { participation } \\
\text { in public } \\
\text { infrastructur } \\
\text { e committee }\end{array}$ & $\begin{array}{l}\text { No } \\
\text { supporting } \\
\text { organization } \\
\text {; Events are } \\
\text { advised by } \\
\text { infrastructur } \\
\text { e; } \\
\text { department } \\
\text { on a case } \\
\text { bases; } \\
\text { Lacking the } \\
\text { civil } \\
\text { participation }\end{array}$ & $\mathbf{Y}$ \\
\hline Japan & $\begin{array}{l}\text { Specific } \\
\text { law, and } \\
\text { establish } \\
\text { PFI basic } \\
\text { guidance }\end{array}$ & $\begin{array}{l}\text { Road, } \\
\text { airport, } \\
\text { sewer, public } \\
\text { accommodati } \\
\text { on, social } \\
\text { welfare and } \\
\text { utility } \\
\text { infrastructure } \\
\text {. }\end{array}$ & $\begin{array}{l}\text { Central } \\
\text { government } \\
\text { and regional } \\
\text { government }\end{array}$ & $\begin{array}{l}\text { PFI } \\
\text { Promoting } \\
\text { Office: } \\
\text { Study the } \\
\text { executive } \\
\text { order PFI } \\
\text { Promoting } \\
\text { Office: Set } \\
\text { out rules } \\
\text { and } \\
\text { guidance }\end{array}$ & $\begin{array}{l}\text { PFI : } \\
\text { Advertising, } \\
\text { promoting, } \\
\text { and } \\
\text { supporting } \\
\text { the audit } \\
\text { from } \\
\text { government. } \\
\text { Project } \\
\text { financing } \\
\text { review: : } \\
\text { magazine } \\
\text { PFI : } \\
\text { Information } \\
\text { integrating } \\
\text { and open for }\end{array}$ & $\mathbf{Y}$ \\
\hline
\end{tabular}

1 For example, when discussing government procurement ethics and transparency measures in a seminar about political morality and government procurement at the Taipei Veterans General Hospital, Gao-Yue Guan erroneously referred to cases related to promoting private participation in infrastructure projects as being related to government procurement. http://homepage.vghtpe.gov.tw/ ged/left1.htm 


\begin{tabular}{|c|c|c|c|c|c|c|}
\hline Nation & Law & Scope & $\begin{array}{l}\text { Administrat } \\
\text { ion }\end{array}$ & $\begin{array}{c}\text { Government } \\
\text { Organizatio } \\
n\end{array}$ & $\begin{array}{c}\text { Non-public } \\
\text { Organizatio } \\
n\end{array}$ & $\begin{array}{c}\text { Private } \\
\text { company } \\
\text { applying } \\
\text { project } \\
\text { by itself } \\
(\mathrm{Y} / \mathrm{N}) \\
\end{array}$ \\
\hline & & & & & reviewing & \\
\hline Canada & $\begin{array}{l}\text { No } \\
\text { specific } \\
\text { law, } \\
\text { establish } \\
\text { several } \\
\text { guidance }\end{array}$ & $\begin{array}{l}\text { Any kind of } \\
\text { public } \\
\text { infrastructure } \\
\text {, be used } \\
\text { between the } \\
\text { public sector } \\
\text { and private } \\
\text { sector as an } \\
\text { alternative - } \\
\text { more elastic }\end{array}$ & $\begin{array}{l}\text { Federal } \\
\text { government, } \\
\text { provincial } \\
\text { government, } \\
\text { city } \\
\text { government }\end{array}$ & $\begin{array}{l}\text { P3s bidding } \\
\text { need to be } \\
\text { approved by } \\
\text { Department } \\
\text { of Finance }\end{array}$ & $\begin{array}{l}\text { PBC help } \\
\text { government } \\
\text { department, } \\
\text { CCPPP's } \\
\text { education } \\
\text { training } \\
\text { program,rese } \\
\text { arch and } \\
\text { publications }\end{array}$ & $\mathbf{N}$ \\
\hline UK & $\begin{array}{l}\text { No } \\
\text { specific } \\
\text { law, } \\
\text { establish } \\
\text { standard } \\
\text { contract, } \\
\text { specificati } \\
\text { on guide } \\
\text { and case } \\
\text { study }\end{array}$ & $\begin{array}{l}\text { Hospital, } \\
\text { school, road, } \\
\text { jail, national } \\
\text { defense } \\
\text { related } \\
\text { construction, } \\
\text { training } \\
\text { center and } \\
\text { building, etc. }\end{array}$ & $\begin{array}{l}\text { Central and } \\
\text { regional } \\
\text { government }\end{array}$ & $\begin{array}{l}\text { 1.Department } \\
\text { of finance: } \\
\text { strategy } \\
\text { manager } \\
\text { 2.Congress } \\
\text { National } \\
\text { Audit } \\
\text { Department } \\
\text { and Public } \\
\text { Account } \\
\text { Committee: } \\
\text { Central } \\
\text { executive } \\
\text { administrator } \\
\text { 3.Local Audit } \\
\text { Committee }\end{array}$ & $\begin{array}{l}\text { 1.Collaboratin } \\
\text { g } \\
\text { Corporation: } \\
\text { Supported } \\
\text { and } \\
\text { developed by } \\
\text { central } \\
\text { government } \\
\text { (public- } \\
\text { private } \\
\text { collaboration } \\
\text { ) } \\
\text { 2.4Ps: Local } \\
\text { promoting } \\
\text { and training } \\
\text { organization } \\
\text { (half-public) }\end{array}$ & $\mathbf{Y}$ \\
\hline $\begin{array}{c}\text { German } \\
\mathrm{y}\end{array}$ & $\begin{array}{l}\text { No } \\
\text { specific } \\
\text { law, } \\
\text { according } \\
\text { to } \\
\text { individual } \\
\text { senate } \\
\text { legislatio } \\
\text { n }\end{array}$ & $\begin{array}{l}\text { School, road, } \\
\text { health care, } \\
\text { energy } \\
\text { supply, } \\
\text { sewage } \\
\text { disposal }\end{array}$ & $\begin{array}{l}\text { Central and } \\
\text { regional } \\
\text { government }\end{array}$ & $\begin{array}{l}\text { Ministry of } \\
\text { Finance, } \\
\text { Ministry of } \\
\text { Transport, } \\
\text { Ministry of } \\
\text { Defense, } \\
\text { Ministry of } \\
\text { Economics }\end{array}$ & $\begin{array}{l}\text { Public and } \\
\text { private } \\
\text { cooperation }\end{array}$ & $\mathbf{Y}$ \\
\hline
\end{tabular}

\section{COMPARISON BETWEEN GPA AND PPP ACTS}

This study compared the Government Procurement Act and the Act for Promotion of Private Participation in Infrastructure Projects for two reasons: to assist government agencies in determining whether they should adopt the Government Procurement Act (when budgeting for public works) or the Act for Promotion of Private Participation in Infrastructure Projects (when obtaining private funds), and to ensure that infrastructure developments satisfy public interest.

Table 2. Comparisons between the two Acts

\begin{tabular}{ll}
\hline \multicolumn{1}{c}{ Project } & \multicolumn{1}{c}{ Comparisons between the two Acts } \\
\hline $\begin{array}{l}\text { Laws related to } \\
\text { government } \\
\text { procurement }\end{array}$ & $\begin{array}{l}\text { 1.PPP: Cites the Statute for Encouragement of Private Participation in } \\
\text { Transportation Infrastructure Projects; }\end{array}$ \\
& $\begin{array}{l}\text { 2. GPA: Cites the Government Procurement Agreement and the Inspection } \\
\text { Ordinance. }\end{array}$ \\
$\begin{array}{l}\text { Drafting of } \\
\text { legislation }\end{array}$ & $\begin{array}{l}\text { Private Participation in Transportation Infrastructure Projects, to ensure that due } \\
\text { diligence is exercised when promoting private participation in infrastructure }\end{array}$ \\
\hline
\end{tabular}




\begin{tabular}{|c|c|}
\hline Project & Comparisons between the two Acts \\
\hline & $\begin{array}{l}\text { projects and to promote public interest; } \\
\text { 2. GPA was enacted to establish an open, transparent, fair, competitive, efficient, } \\
\text { trustworthy government procurement system in accordance with the Inspection } \\
\text { Ordinance and WTO Agreement on Government Procurement. }\end{array}$ \\
\hline $\begin{array}{l}\text { Purpose of } \\
\text { legislation }\end{array}$ & $\begin{array}{l}\text { 1. PPP was introduced to enhance the quality of public services, promote private } \\
\text { participation in infrastructure projects and to stimulate economic development; } \\
\text { 2. GPA was introduced to establish a fair procurement procedure. }\end{array}$ \\
\hline $\begin{array}{l}\text { Application of } \\
\text { legal regulations }\end{array}$ & $\begin{array}{l}\text { According to the Executive Yuan, government agencies shall promote private } \\
\text { participation in infrastructure projects in accordance with the Act for Promotion } \\
\text { of Private Participation in Infrastructure Projects. }\end{array}$ \\
\hline $\begin{array}{l}\text { Characteristics } \\
\text { of legal } \\
\text { regulations }\end{array}$ & $\begin{array}{l}\text { 1. PPP contains two chapters pertaining to promoting public interest (i.e., Land } \\
\text { Acquisition and Development; Financing and Tax Benefits); } \\
\text { 2. GPA contains two chapters pertaining to fraud prevention (i.e., Dispute } \\
\text { Settlement, Protest, and Complaint; and Penal Provisions). }\end{array}$ \\
\hline $\begin{array}{l}\text { Implementation } \\
\text { procedures }\end{array}$ & $\begin{array}{l}\text { 1. PPP: The government shall provide land and buildings; private investors shall } \\
\text { provide funding; the procedure for land development or inviting investors shall } \\
\text { be conducted openly and fairly, emphasizing the importance of cooperation; } \\
\text { 2. GPA: The government shall provide funding and suppliers shall provide } \\
\text { construction technology, labor and company property. Throughout the } \\
\text { procurement, the government shall provide funding and maintain control of the } \\
\text { procedure; private investors shall provide assistance if necessary. }\end{array}$ \\
\hline $\begin{array}{l}\text { Scope of } \\
\text { application }\end{array}$ & PPP and GPA differ in their defined scope of application. \\
\hline $\begin{array}{l}\text { Relevant } \\
\text { agencies }\end{array}$ & $\begin{array}{l}\text { 1. Cases in which PPP is applicable: The authority in charge, authorized } \\
\text { institutions and commissioned agencies; } \\
\text { 2. Cases in which GPA is applicable: Government agencies, public schools, } \\
\text { government-owned enterprises, entrusted corporations or groups, and other } \\
\text { agencies of professional capacity. }\end{array}$ \\
\hline $\begin{array}{l}\text { Private } \\
\text { participation in } \\
\text { infrastructure } \\
\text { projects }\end{array}$ & $\begin{array}{l}\text { 1. PPP contains two procedures pertaining to announcements made by the } \\
\text { government and planning undertaken by private institutions; } \\
\text { 2. GPA states that the government shall control the implementation procedure; } \\
\text { suppliers cannot plan their level of participation. In addition, the Act for } \\
\text { Promotion of Private Participation in Infrastructure Projects applies to cases } \\
\text { involving private participation in public construction. }\end{array}$ \\
\hline $\begin{array}{l}\text { Public procedure } \\
\text { for inviting } \\
\text { public } \\
\text { participation }\end{array}$ & $\begin{array}{l}\text { 1. PPP: The government shall invite investors and cooperate with private } \\
\text { institutions openly and transparently; } \\
\text { 2. GPA: Regarding a fair procurement procedure, the government shall announce } \\
\text { information on invitations to tender in the Government Procurement Gazette and } \\
\text { online. Thus, the Act for Promotion of Private Participation in Infrastructure } \\
\text { Projects is more open and transparent compared with the Government } \\
\text { Procurement Act. }\end{array}$ \\
\hline $\begin{array}{l}\text { Confidentiality } \\
\text { provisions }\end{array}$ & $\begin{array}{l}\text { 1. PPP: Except for the negotiation process and review content, other procedures } \\
\text { related to inviting investors shall be conducted openly and transparently; } \\
\text { 2. GPA: Tender documentation shall remain confidential before the documents are } \\
\text { published; the reserve price as well as the list and number of suppliers that have } \\
\text { submitted tenders shall not be revealed before the opening of tenders. }\end{array}$ \\
\hline $\begin{array}{l}\text { Negotiation } \\
\text { mechanisms }\end{array}$ & $\begin{array}{l}\text { 1.PPP: Documents related to inviting investors state that negotiations may be } \\
\text { undertaken to facilitate selecting the best applicant; } \\
\text { 2. GPA: When the awarding of a contract cannot be decided, the contract may be } \\
\text { awarded through negotiations, but only after the entity has received approval } \\
\text { from the superior entity and after announcing such intentions in the tender } \\
\text { documentation. }\end{array}$ \\
\hline $\begin{array}{l}\text { Selection and } \\
\text { review } \\
\text { procedures }\end{array}$ & $\begin{array}{l}\text { 1. Selection Committee members: In accordance with PPP, the list of Selection } \\
\text { Committee members may be announced in tender documentation provided that } \\
\text { all Selection Committee members agree unanimously; in accordance with the } \\
\text { Government Procurement Act, the list of Procurement Evaluation Committee } \\
\text { members shall remain confidential; } \\
\text { 2. Chairperson: In accordance with the Act for Promotion of Private Participation } \\
\text { in Infrastructure Projects, the chairperson of the Selection Committee shall be } \\
\text { elected by the Selection Committee; in accordance with the Government } \\
\text { Procurement Act, the chairperson shall be a senior member of the agencies. }\end{array}$ \\
\hline Bid selection and & 1. PPP: Negotiation and execution of concession agreements; \\
\hline
\end{tabular}




\begin{tabular}{ll}
\hline \multicolumn{1}{c}{ Project } & \multicolumn{1}{c}{ Comparisons between the two Acts } \\
$\begin{array}{l}\text { contract signing } \\
\text { procedure }\end{array}$ & $\begin{array}{l}\text { 2. GPA: Negotiation and comparison of procurement tenders followed by the } \\
\text { execution of concession agreements. }\end{array}$ \\
\hline $\begin{array}{l}\text { Bid bond and } \\
\text { security deposit }\end{array}$ & $\begin{array}{l}\text { 1. PPP: No regulations are stipulated regarding the confiscation of the security } \\
\text { deposit in order to encourage cooperation between the government and private } \\
\text { institutions; }\end{array}$ \\
& $\begin{array}{l}\text { 2. GPA: The bid bond is not returned and security deposit is confiscated. } \\
\text { Nature of } \\
\text { contract }\end{array}$ \\
$\begin{array}{l}\text { contracts. This Act removes the power possessed by the government for } \\
\text { administrative contracts and promotes cooperation between the government and } \\
\text { private institutions on the basis of equality; }\end{array}$ \\
2. GPA: The government determines how to formulate procurement contracts.
\end{tabular}

Table 3. Rules for promoting public interest and preventing fraud

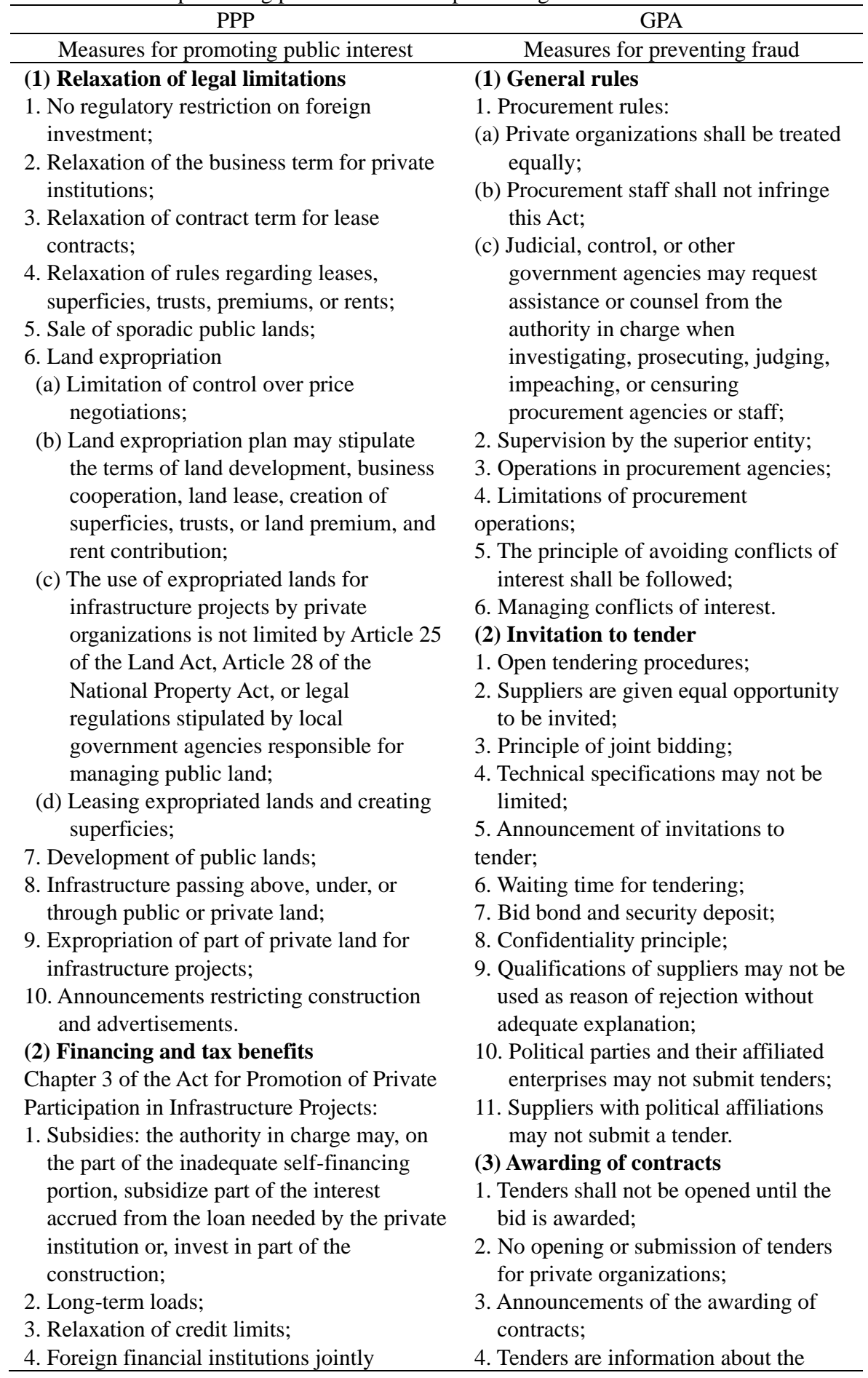




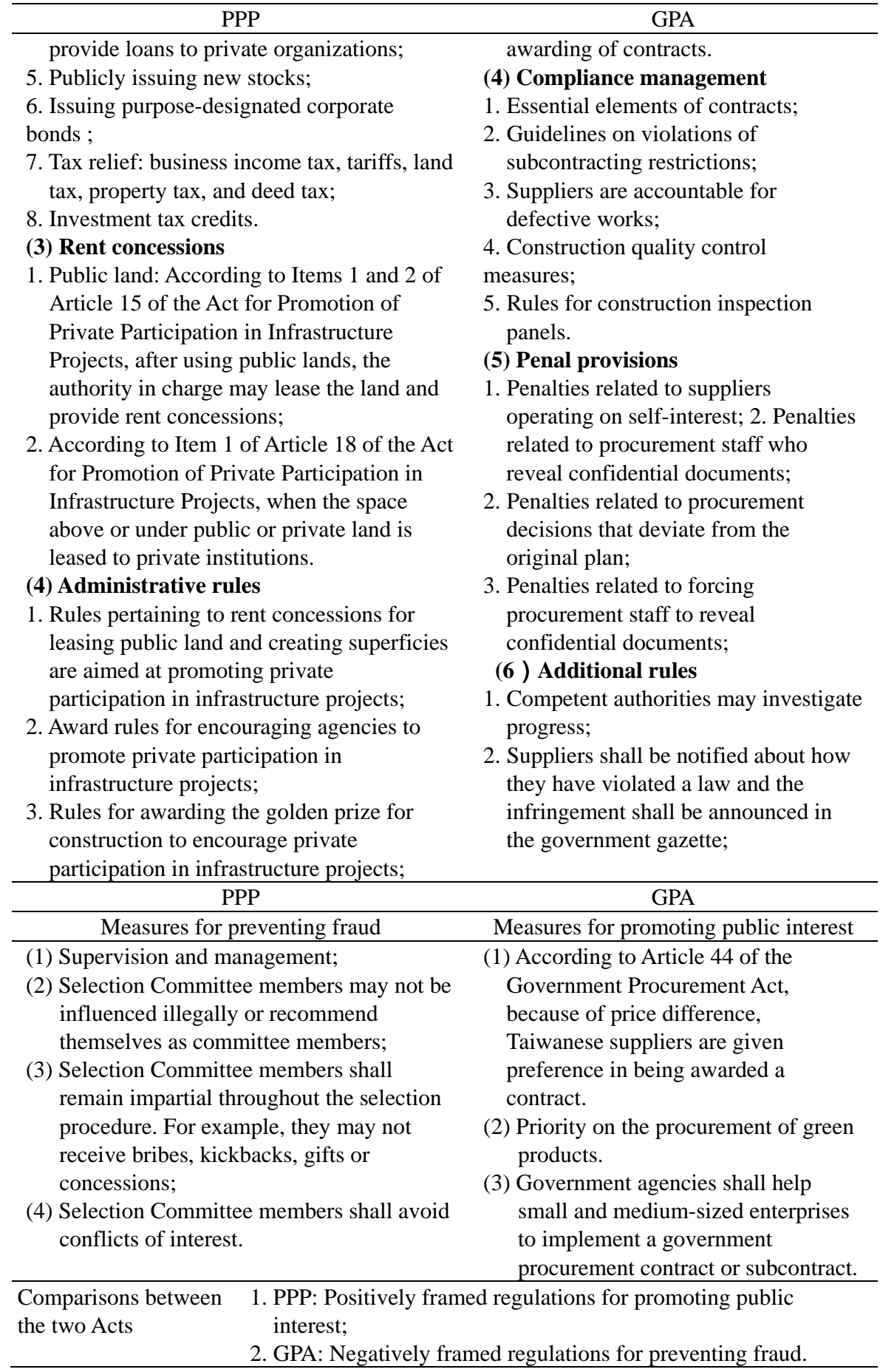

\section{CONCLUSION}

(1) In this study, the Act for Promotion of Private Participation in Infrastructure Projects and the Government Procurement Act were reviewed and compared because the historical background, legislative purpose, implementation procedures, transparency and confidentiality regulations are fundamentally different between the two Acts. Executives should avoid erroneously misapplying laws.

(2) The Government Procurement Act contains more regulations related to preventing fraud compared with the Act for Promotion of Private Participation in Infrastructure Projects. The rules on confidentiality are as 
follows: the content of tender documentation and the reserve prices shall remain confidential until the winning applicant is announced. Through the principle of confidentiality and a fair procurement mechanism, the quality of procured products can be assured. The Act for Promotion of Private Participation in Infrastructure Projects covers more concession regulations than does the Government Procurement Act. Providing an open and transparent mechanism facilitates the acquisition of private investors. Through implementing such a mechanism, government agencies can improve investor confidence.

\section{RECOMMENDATIONS}

Currently, regarding implementing the Act for Promotion of Private Participation in Infrastructure Projects, the differences between service provision and gaining illegal profits cannot be distinguished; therefore, civil servants are reluctant to take on additional responsibility in fear of being held accountable. Based on the findings of this study, the following recommendations are proposed to provide a reference for government agencies to promote private participation in infrastructure projects:

(1) Because of the zero premium and rebates, public construction does not benefit public interest. In an investment contract, unusually high operating profits should be reported and premiums and rebates should be increased.

(2) The amount of funding that private institutions can acquire from banks should be limited in order to reduce the level of risk exerted on the government when private institutions fail to operate as contracted.

(3) The Act for Promotion of Private Participation in Infrastructure Projects should be clearly defined to facilitate mutual trust and cooperation between the government and suppliers in order to promote private participation in infrastructure projects.

(4) Executives at government agencies should receive adequate training to ensure that they possess the required professional skills and knowledge to facilitate the establishment of specialized consultancies.

(5) Government employees, including judicial officials, accounting and statistics officers, auditors, investigators and ethics officials, should be invited to seminars to achieve consensus about the Act for Promotion of Private Participation in Infrastructure Projects and raise awareness of the Act for Promotion of Private Participation in Infrastructure Projects and the Government Procurement Act.

(6) The Act for Promotion of Private Participation in Infrastructure Projects should be amended to include regulations requiring government agencies to seek counsel or counsel from competent agencies when investigating, prosecuting, judging, impeaching and censuring agencies or people who are responsible for promoting private participation in infrastructure projects.

(7) Because prosecutors and judges are subject to human error, a professional advisory committee, specialized court or jury system should be established to handle cases related to promoting private participation in infrastructure projects in order to prevent judges with inadequate knowledge, job experience or empathy from making misjudgments, which can make civil servants become conservative in developing national infrastructure and utilizing public assets. 


\section{REFERENCES}

Deautschland, P. (2008). "The Market for Public-Private Partnerships in Germany". http://www.unece.org/fileadmin/DAM/ceci/ppt_presentations/2008/ppp/Moscow/muller.pd f.

Division for Promotion of Private Participation, Ministry of Finance. (2006a). "Investigation into the Compliance Phase of Private Participation Cases and Related Suggestions". Retrieved from http://ppp.mof.gov.tw/PPP.Website/News/Display.aspx?ID=652 on 1 May, 2015.

Division for Promotion of Private Participation, Ministry of Finance. (2006b). "Private Participation in Infrastructure Projects and Comparison between Act for Promotion of Private Participation in Infrastructure Projects and Government Procurement Act". Retrieved from http://ppp.mof.gov.tw/PPP.Website/News/Display.aspx?ID=668 on 1 May, 2015.

Elbing, C., \& Wettengel, P. (2011). "Recent Trends and Developmentsof Ppp in Germany". Retrieved from https://www.ppp.gov.pl/KonferencjeIseminaria/Documents/1_110426_PD_Workshop_War saw Block\%20I.pdf

Institute of Transportation, Ministry of Transportation and Communications. (2009). Private Participation in Infrastructure Projects. Taipei, Taiwan.

Li, Z. X. (2015). "The Development and the Prospects of Promoting Private Participation in Infrastructure Projects". Retrieved from http://www.cepd.gov.tw/dn.aspx?uid=7404 on 1 Mar, 2015.

Ministry of Finance. (2014). "Questions and Answers in the Conference for Promoting Private Participation (Accounting, Auditing, Accounting and Statistics, Political Morality, and Prosecutors)" (Taicaicuzi number: 10325513240).

Ministry of Finance. (2015). "Promotion of Private Participation Website". Retrieved from http://www.google.com.tw/url?url=http://ppp.mof.gov.tw/ppp.admin/DownFile.aspx\%3Ffr omto\%3Dwebsite $\% 26$ ReferId\%3D2762\&rct=j\&frm $=1 \& q=\&$ esrc $=\mathrm{s} \& \mathrm{sa}=\mathrm{U} \& \mathrm{ved}=0 \mathrm{CBgQ}$ FjABahUKEwitvOCGvL7GAhWTEbwKHWHQCoI\&usg=AFQjCNGPE7n484uavZyHiI WPiOnFBcmXUwhttp://www.unece.org/fileadmin/DAM/ceci/ppt_presentations/2008/ppp/ Moscow/muller.pdf

Public Construction Commission, Executive Yuan. (2007). Defects About Promotion of Private Participation in Infrastructure Projects. Taipei, Taiwan.

Public Construction Commission, Executive Yuan. (2016a). "The Governments on Signing the Gpa". Retrieved from https://www.pcc.gov.tw/pccap2/TMPLfronted/ChtIndex.do?site=002 on 2 April, 2016.

Public Construction Commission, Executive Yuan. (2016b). "International Trend of Ppp". Retrieved from https://www.pcc.gov.tw/epaper/9804/face03.html on 2 April, 2016.

The Legislative Yuan of the Republic of China. (1994). "The Legislative Content for Government Procurement Act". Paper presented at the The Relation Bill for the 28th Meeting in the 3rd Session of the 2nd Legislative Conference.

The Legislative Yuan of the Republic of China. (1998). "The Legislative Content for Act for Promotion of Private Participation in Infrastructure Projects". Paper presented at the The Relation Bill for the 2nd Meeting in the 6th Session of the 3rd Legislative Conference. 